\title{
LCL Model Experiential Learning based Training Model Development to Improve Teacher Competence in Designing Learning
}

\author{
Eva Nirtha1* ${ }^{1 *}$ Bambang Ismanto ${ }^{2}$, Bambang Suteng Sulasmono ${ }^{3}$ \\ 1,2,3 Universitas Kristen Satya Wacana, Salatiga, Indonesia \\ *e-mail: evanirtha34@gmail.com
}

\begin{abstract}
Teacher's competence in designing learning is one of the important aspects in getting the success of education. Based on preliminary research, any teacher didn't make a learning design in teaching. Professional teacher certainly has variety experiences. However, experience-based training has rarely been given for the professional teacher. This research aimed to produce and determine the effectiveness the LCL model-based Experiential Learning training model to improve teacher competence in designing learning. It was developed based on Borg and Gall R\&D model, carried out until the seventh stage using qualitative and quantitative approaches. The average validity score is 82.5 categorized as highly deserving by validators. ANCOVA's test results showed that there is a significant difference between classes, with the value of $[F=(1,58), D=83,29, \rho=0.000, \eta \rho 2=0,58]$ significance value $\rho=0.05$. Based on the LSD table, the average corrected value of the treatment group was 72.84 , while the control group was 45.69 . It concluded that the training model is feasible and effectively used. This training model can be used as an alternative training to improve teacher competence, especially in designing learning that meets the elements of the 21 st century learning paradigm and it has been completed by training tools such as module, guides and necessary handsout.
\end{abstract}

Keywords: R\&D, Training Model, Experiential Learning, Teacher Competence

\section{Introduction}

Teacher competence in designing learning is an important aspect to achieve educational success (Hakim, 2015; Hidayat Ada \& Azisah, 2016; Nabila, 2011). Good teacher competence can contribute positively to students' achievements (Herminayu \& Sulasmono, 2020; Novauli. M, 2015; Rafli, 2017). However, based on previous study, $37 \%$ of teachers did not do learning plan (Zendrato, 2016). Whereas professionally, teachers must be able to design and implement learning well, so that learning objectives will be achieved effectively (Mawardi, 2018; Prihidayanti et al., 2019). Besides, the National Teacher Competency Test (UKG) 2015 data showed that the average competency of teachers is still low with an average score of 48.94 below the National Minimum Competency Standard of 55.0. So it can be concluded that the competence of teachers in designing learning is still low.

Competency is a complex set of abilities as a basic requirement to be used and displayed in job performance, obtained through certain levels of education and training process as an absolute requirement. Thus, the understanding of the teacher's competence also applies to teachers. Based on Law No. 14 of 2005 article 8, teacher competence is divided into 4 parts, namely professional, pedagogic, personality and social competencies. The ability of teachers to manage the learning process is part of pedagogic competence (Fathorrahman, 2017). While the ability of teachers in mastering the material broadly and deeply is professional competency. Furthermore, the teacher's ability to have a steady personality, stable adult, wise and authoritative, noble character and even be a role model and role model for learners is part of personality competence. As well as the ability of teachers in interacting and communicating effectively and efficiently with students, fellow

\footnotetext{
${ }^{*}$ Corresponding author.
}

Received April 14, 2021; Accepted June 20, 2021; Available online September 25, 2021

Copyright (@ 2021 by Author. Published by Universitas Pendidikan Ganesha. 
teachers, parents and even the wider community is part of social competence. Thus teachers need to have qualified competencies for the success of education to be achieved (Kunter et al., 2013; Lase, 2019; Widyaningrum et al., 2019).

Various efforts were made to improve teacher competence, including through teacher certification and training programs (Permana, 2017; Tyagita \& Iriani, 2018). However, certification efforts have not had a significant impact on improving teacher competence. Previous study found that $46.7 \%$ of teacher certifications influenced teacher performance based on determination test results, relative variable donation test results were $43.3 \%$, effective donations were $20.2 \%$ and the rest were influenced by other factors (Kurnia, 2012). On the research of Lalupanda et al, 2019, there is a gap between the expected ideal conditions and the real conditions in the field in the teacher certification program.

Teacher training has also not been able to help improve teacher competence, because the training has several weaknesses including training has not been able to answer the needs of teachers that vary, participants entering retirement age tend to be less enthusiastic and the training is still partial (Wulandari \& Iriani, 2018). Thus, the training needs to be done but adapted to the needs of teachers in the field so that the problem of improving teacher competence can be done through training activities. Because, every organization needs the training to create better job performance, organizational development and achieving previously set goals (Karia \& Omari, 2017; Kumar \& Siddika, 2020; Nusanti, 2017) No exception in training and development for schools that are organization in educational institutions (Ibrahim et al., 2017).

The phenomenon of low competence of teachers is also experienced by teachers in North Luwu Regency, South Sulawesi Province. Based on regional education balance data (NPD 2015), the results of teacher competency test, especially pedagogic competency and professional teachers in South Sulawesi got an average score of 52.55 below the national standard average of 55.0. The results of the initial field study also showed that there is a trend of decreasing the value of teacher competence in the teacher's driver's license report. On average, 1 to 4 out of 10 competencies show the remaining competent teachers are incompetent. Based on the results of an interview with a principal and a total of 12 certified teachers in the North Luwu district, two teachers stated that their learning seemed monotonous from year to year, so they needed a training activity that was able to help them improve their insights and skills in teaching. Meanwhile, according to the principal's explanation, the school has an alternative plan of internal training, but it is constrained to the source of training, both the availability of facilitator and other technical problems. The headmaster has been hoping that MGMP as a training platform can help teachers improve their competencies. However, the training has shown that there are several limitations in the containers, sources, frequencies, types of training and measuring instruments used to measure teacher competence after attending training activities exacerbated by the low level of teacher awareness of the importance of improving teacher competence through training. Thus, a training model is needed that suits the needs of teachers.

According to the result of preliminary studies on education and training to improve teacher competence and teaching skills can be done through education and training with Experiential Learning model (Bohon et al., 2017). Based on the teacher need in US for teaching methods in the classroom with the diversity cultures and different languages, the teachers overcome problems in helping student to achieve achievement but is constrained by the use of English. So that, it's shown the student in question is quite smart but do not experience learning. Thus, the education financing department in the US, namely Assisting, Collaborating, and Training ESL Content Secondary Teacher (ACS-ESL) expects highquality professional development, especially in concepts and methods for learners to use English by teachers as secondary content to help meet academic needs and learners speak English and improve academic achievement. This study's intensive teacher training program was designed with a multistage and effectiveness test of the Summer Institute on participants in teaching English language learning using Experiential Learning. The result of this study indicated that Experiential Learning is very effective when the steps are applied in learning, the teachers can conclude by themselves the change in the learning method they have been 
doing so far, and in demonstration activities, it is possible for teachers to gain expertise and understanding of teachers which are increasingly complex because of the integration of various learning concepts. Furthermore, the research conducted on education and training for pre-service teachers at inclusive schools in South Korea using Experiential Learning, the result of this study indicates that there has been change in teacher beliefs about children with the special needs in learning science with an inclusive environment. The pre-teacher realized that the students with special needs were individual and group learners. Even though a learner has a severe disability, he or she can be a better learner than other members of the learner who have fewer levels of disability (Kang \& Martin, 2018). Next, the positive impact due to the interaction between teachers and inclusive learners, including pre-service teachers can gain new knowledge about teaching strategies for children with special needs in inclusive classes, for example, the importance of implementing individual learning plans (IEP). Experiential Learning then develops with reflection activities which are very useful in changing teachers' beliefs and practices towards children with special needs and inclusive education. Therefore, in education, teachers are enabled to develop their imagined professionalism in teaching science to all students in the future (Kang \& Martin, 2018). The other research regarding experiential learning strategies involving prospective teachers at a university in Tanzania, especially in teaching educational environment as the crucial topic in that area. The result of this research showed that the learning strategy is carried out into four steps of EL learning and researchers conclude the effectiveness of the intervention, where prospective teachers can create and implement teaching modules outside the classroom with limited socio-cultural and resource contexts. Then prospective teachers can be responsible for teaching environmental education in the situation of new participants and limited environments. So that the researchers conclude that experiential learning is very suitable to be applied in learning (Kalungwizi et al., 2020).

Therefore, to fix the weaknesses of training that have been done, it is necessary to develop a training model that suits the needs of teachers (Gunawan et al., 2020; Slameto et al., 2017; Suherman, 2014). Based on interview results, small-scale research, observation sheets, teacher document studies by checking teacher RPP, teacher competency test results based on teacher PKB report, UKG results on Education Balance Data and literature studies, researchers conducted research and product development in the form of Experiential Learning-based training models. Experiential Learning-based training is proven to assist teachers and prospective teachers in improving their competencies (Bohon et al., 2017; Kalungwizi et al., 2020; Kang \& Martin, 2018). This research shows that if the four steps of Experiential Learning are conducted then the training will be very effective in helping teachers and prospective teacher to improve their competence. However, explicit reflection activities helped to realize teachers' negative views of students with special needs. Meanwhile, the reflection process involves three different activities including, writing emotions, thoughts and things related to the teacher's emotions, disclosure and discussion of reflection results in the group. Thus, in the third step of Experiential Learning-based training, there are different activities in the reflection process with the same goal of raising awareness of teachers. Because there are technical differences in the reflection of Experiential Learning-based training, more detailed Experiential Learning-based training activities are required at each stage according to the training objectives

The LCL model of Experiential Learning-based teacher training is a learning model presented in a visual metaphor of six tumblers that represents the complexity of choice inexperience. Training objectives on LCL models can be achieved through the six dimensions possessed on each tumbler. In the first tumbler discuss the environment or place that contributes to the experience, be it artificial or natural environment, virtual or real, abstract or conceptual, indoor or outdoor. In the second tumbler discussing activities involving both physical and non-physical can be designed to shape the experience. The third tumbler involves the way used to derive meaning from learning activities through the senses of both hearing, vision and other senses. On the fourth tumbler about the emotional involvement of learners, be it fun, depressing, or other emotional variety. Then the fifth tumbler is an element of forming a mindset and inviting people to think about what to do 
based on the experience that has been gained. The sixth tumbler is a dimension of existence, helping a learner do something based on their awareness and risks that must be borne. In previous research, a training model with an Experiential Learning approach was applied to foreign language subject teachers and prospective teachers. While this research will be applied to various teachers of the field of study who has been certified.

Effectiveness tests in previous studies using Cohen's d analysis, while in this study using ANCOVA analysis techniques. The effectiveness or positive impact of the four steps of Experiential Learning also proved by Clarke (Clarke, 2017) in journalistic class and also Tanjung in making a vlog Experiential Learning (Tanjung, 2019). Actually, Experiential learning is able to be applied in several different departments (Breunig, 2017; Coker et al., 2017; Mason \& Arshed, 2013; Matsuo, 2014; Shoulders et al., 2014), but in this research, Experiential Learning was applied in education department. So based on these advantages, it is necessary to conduct research and development and test the effectiveness of the training model based on the LCL Model Experiential Learning. With the hope that there will be an increase in teacher competence in designing learning and bring benefits for teachers and students in the learning process and teaching in class for the future. This research aimed to produce and determine the effectiveness the LCL model-based Experiential Learning training model to improve teacher competence in designing learning.

\section{Method}

This research is a Research and Development (R\&D) study using the Borg \& Gall model (Verdina et al., 2018), but it is limited to the seventh step and in the third step, modified using the 10 step Dick \& Carey model. The modification of R\&D procedure is presented as follows: In the early stages, researchers conducted small-scale research in North Luwu Regency on February 17-18, 2020 at UPT SMPN 3 Sukamaju and SMPN 1 Sukamaju Selatan to obtain information, using interview guidelines, observation sheets, document studies, checklists and literature studies. At the planning stage, the formulation of research and development objectives must be achieved, identifying the skills and insights to be studied, as well as the selection of development models used in developing instructional models. The product development phase uses detailed development steps by Dick and Carey (Mawardi, 2018). Among others, identify participants, objectives and initial conditions before training, conduct learning analysis, formulate performance, develop assessment instruments, develop learning strategies, design and conduct formative evaluations, revise learning and conduct summative evaluations. Furthermore, the initial field test was conducted in 3 schools, namely UPT SMPN 1, 2 and 3 Sukamaju, with the number of test subjects as many as 7 test subjects.

In the main product revision stage, product design improvement and validation by product experts and training instruments are carried out. Suggestions, inputs and assessment results of training model products are used as a reference in the main field tests. The main field test, as well as the effectiveness test using a quasi-experimental design with a systematic selected control group approach, was conducted in 12 schools and 60 test subjects. In the main field test, the training model was tested in a treatment group of 30 participants who met the criteria of six state junior high schools, namely SMPN 2 Bone-Bone, SMPN 1 Tanah Lili, SMPN 1 Mappideceng, SMPN 1 Baebunta and SMKN 1 Luwu Utara. The trial was conducted on 2 consecutive days, namely, on Saturday and Monday, 28 to 30 November 2020, starting from 08.00-14.00 WITA. While the control group, the training was attended by 30 participants from six junior high schools, namely SMPN 1, 2 and 3 Sukamaju, SMPN 1 Sukamaju Selatan, SMPN 2 Malangke, and MTs Wonokerto. Instruments used are observation sheets, questionnaires, tests (pre-post tests). Furthermore, the main field test results are used to revise operational products. Validity test techniques and analysis of research data are validated using triangulation techniques for qualitative data, while experimental design validated using external and internal validation. For external validation, it can be reviewed from a comparison of the results of other similar studies based on the results of identification and description of the dominant elements contained in a particular 
phenomenon. Analysis of quantifiable data using a single-track Anakova (One Way ANCOVA) (Sa'adah et al., 2017), described in Table 1.

Table 1. ANCOVA One Way Design

\begin{tabular}{cccccc}
\hline & $\mathbf{A}$ & & & $\mathbf{B}$ & \\
\hline $\mathbf{X}$ & & $\mathbf{Y}$ & $\mathbf{X}$ & & $\mathbf{Y}$ \\
\hline
\end{tabular}

Furthermore, determining the pre-conditions of ANCOVA test, as follows: 1) bound variable is interval and ratio data, 2) free variable in the form of categorical data that divides data into two groups, 3) Observation Independence, 4) Using residual data, 5) Normality and Linearity test of residual data, 6) Homogeneity test, 7) Homogeneity slope regression.

\section{Result and Discussion}

\section{Results}

The final result of this research and development is a product of the LCL-based Experiential Learning model training model equipped with modules, participant guides, trainer guides and evaluation guides that have proven effectiveness. The results of each stage in the research and development (R\&D) Borg and Gall conducted until the seventh step are as follows: The results at the preliminary research and information gathering stage showed that certified teachers in the North Luwu district experienced monotonous teaching and learning activities from year to year, there are still teachers not implementing the design of the learning made or teachers make the design of the implementation of learning for the fulfilment of administration alone, the low level of teacher awareness of the importance of a learning plan and training, and the low competence of teachers based on the value of the teacher's PKB report in 2017-2019 so that the learning carried out does not change from year to year or is monotonous. Based on the results of interviews with 3 principals and 10 teachers, teachers have received training but the training followed by teachers has several skills including training is not as needed, training is partial, training does not use hand out and the availability of facilitators. Field findings on certified teachers show that there is a gap between real conditions in the field and the expected ideal conditions. (Widowati 2012, Lalupanda et al, 2019). So from the information, literature studies and results from literature studies show that teacher competence can be improved through Experiential Learning-based training (Bohon et al., 2017; Kalungwizi et al., 2020; Kang \& Martin, 2018). At the planning stage also produces the formulation of goals and competencies to be achieved, the formulation of budgets, time and training personnel as well as the selection of development method design using the Dick \& Carey model and hypothetical model. And the results of the analysis of the training model is used to create a blueprint of the training model, which is useful to store information about the objectives, implementation design to the expected results of the training model.

The results of development using the Dick \& Carey model based on each stage are as follows: the results of the identification stage of prospective trainees, the purpose and condition of pre-training, resulting in a checklist of participants, modules, and guidelines to be used in the training. The results of instrument development resulted in performance assessment instruments, questionnaires and observation sheets of trainees, training organizers and facilitators, validation sheets, committee attendance lists, trainees, facilitators, as well as reflection sheets and other measuring instruments. The results of the development of learning strategies, resulting in an overview of the series of training activities, formative evaluation design resulting informative test questions and answer sheets, in the step of revising integrated learning in the fifth and seventh steps of R\&D Borg and Gall and conducting summative evaluation, at this stage produced an integrated summative evaluation sheet in the sixth step of R\&D Borg \&Gall. The test results at the preliminary field testing showed that the training model got a pretty good score with an average score of 2.1 questionnaire results and the observation results got an average score of 3.8 in the very 
good category. The results at the main product revision stage, the training model based on Experiential Learning LCL model has been valid, meaning it has the validity to be used and further tried by making revisions to the directives. The revisions include rearranging the words in the model title and module.

The calculation result of the validation data analysis based on each product expert and training expert, obtained a model feasibility value of 92.4 which is a very worthy category, module 81 feasibility value, 80 trainee guide, 89 trainer guide and evaluation guide which overall category is very feasible by product expert validator. While the feasibility score is 73.5 for training models with a decent category, 77 for training modules categorized as highly feasible, and 75 for each guide and instrument categorized as worthy by instrument and training expert validators. The average validation result of both experts is 82.5 categorized as very decent. Thus the training product can be used as the validators direction. The results of the main field test stage using ANCOVA test, assisted by IBM SPSS 25 , which has previously met ANCOVA test criteria including data used are residual data and parametric test i.e. normality test, homogeneity test and linearity test. So obtained ANCOVA test results as shown in Table 2.

Table 2. ANCOVA Test Result

\begin{tabular}{|c|c|c|c|c|c|c|}
\hline \multicolumn{7}{|c|}{ Descriptive Statistics } \\
\hline \multicolumn{7}{|c|}{ Dependent Variable: post-test score } \\
\hline Kelas & Mean & & \multicolumn{2}{|c|}{ Std. Deviation } & \multicolumn{2}{|c|}{$\mathbf{N}$} \\
\hline $\mathrm{E}$ & \multicolumn{2}{|c|}{74.13} & \multicolumn{2}{|r|}{10.348} & \multicolumn{2}{|r|}{30} \\
\hline $\mathrm{K}$ & \multicolumn{2}{|c|}{44.30} & \multicolumn{2}{|r|}{14.730} & \multicolumn{2}{|r|}{30} \\
\hline Total & \multicolumn{2}{|c|}{59.22} & \multicolumn{2}{|r|}{19.636} & \multicolumn{2}{|r|}{60} \\
\hline \multicolumn{7}{|c|}{ Tests of Between-Subjects Effects } \\
\hline \multicolumn{7}{|c|}{ Dependent Variable: post-test score } \\
\hline Source & $\begin{array}{l}\text { Type III } \\
\text { Sum of } \\
\text { Squares }\end{array}$ & Df & Mean Square & $\mathbf{F}$ & Sig. & $\begin{array}{l}\text { Partial } \\
\text { Eta } \\
\text { Squared }\end{array}$ \\
\hline $\begin{array}{l}\text { Corrected } \\
\text { Model }\end{array}$ & $13350.417^{a}$ & 1 & 13350.417 & 82.394 & .000 & .587 \\
\hline Intercept & 210396.817 & 1 & $\begin{array}{r}210396.81 \\
7\end{array}$ & 1298.502 & .000 & .957 \\
\hline Kelas & 13350.417 & 1 & 13350.417 & 82.394 & .000 & .587 \\
\hline Error & 9397.767 & 58 & 162.030 & & & \\
\hline Total & 233145.000 & 60 & & & & \\
\hline $\begin{array}{l}\text { Corrected } \\
\text { Total }\end{array}$ & 22748.183 & 59 & & & & \\
\hline
\end{tabular}

The results of the data interpretation from the ANCOVA Test table are as follows: 1) Test the use of models with control over the initial data, the results of data processing are seen that the significant figure for the change of learning model is 0.000 . Because of the significance of Sig. $<0.05, \mathrm{H}_{0}$ is rejected. So it can be concluded that by controlling the initial ability of the trainees (pretest), there are differences in learning outcomes between the trainees who use the LCL model and the one-way lecture model. 2) The influence of differences in learning models on the value obtained by the trainees can simultaneously be seen from the significant figures in the corrected part of the model. The significant number is 0.000 . Because the significance number is 0.000 . This significant number is well below the number $0.05(\mathrm{sig}<0.05)$ then $\mathrm{H}_{0}$ is rejected. So at a confidence level of $95 \%$, it can be concluded that simultaneously, the learning model affects the value obtained by the trainees. 3) Measurement of how much influence the learning model has on the learning outcomes of the trainees can be measured based on effect size using Partial Eta Square because Partial Eta Square describes the proportion of total variance caused by factors or paying attention to the influence of other variables. So based on Partial Eta Square, the influence of the learning 
model by $58.7 \%$. Thus, it can be summarized the results of the ANCOVA test above are as follows: by controlling the initial ability of the trainees, ANCOVA's analysis (One Way ANCOVA) showed that there were significant differences between one class and another with $[F=(1.58)=82,394 . \rho<0,000, \eta \rho 2=0.58$ based on the significance value of $\rho<0.005$. Further test results have been provided with the following LSD data as shown in Table 3.

Table 3. LSD Test

\begin{tabular}{ccccc}
\hline \multicolumn{4}{c}{ Estimates } \\
\hline \multirow{3}{*}{ Kelas } & Mean & Dependent Variable: & postest \\
\cline { 3 - 4 } & & Std. Error & 95\% Confidence Interval \\
\cline { 3 - 4 } & & 1.983 & Lower Bound & Upper Bound \\
\hline LCL & $72.837^{\mathrm{a}}$ & 68.865 & 76.808 \\
CSA & $45.686^{\mathrm{a}}$ & 2.003 & 41.673 & 49.699 \\
\hline
\end{tabular}

Based on LSD table, the average corrected value of the treatment group was 72.84 , while the control group was 45.69. This indicates that the average corrected value of the experimental class is higher than the corrected average value of the control class. It concluded that the training model is feasible and effectively used.

\section{Discussion}

In the preliminary research and information, there were several weaknesses of the teacher training model that has been given for certified teachers, such as training is not as needed, training is partial, training does not use hand out and the availability of facilitators, therefore the certified teachers couldn't improve their competence in designing learning. The learning process monotonous year to year and exacerbated by the low level of teacher awareness of the importance of training. Whereas the teacher have strategic role in advancing education (Astutik \& Roesminingsih, 2021).

Based on that need analysis, the LCL model of Experiential Learning-based teacher training was developed by Borg \& Gall R\&D model until the seventh stage modified by Dick and Carey model on the third stage that is expected to bridge the gap teachers need for training. According to the results of the ANCOVA test showed that there were significant differences between one class and another with $[F=(1.58)=82,394 . \rho<0,000, \eta \rho 2=0.58$ based on the significance value of $\rho<0.005$. It means that this model is effective to improve teacher competence in designing learning. The model was validated by product and training expert with the average validation result of both experts is 82.5 categorized as very decent. Thus the training product can be used as the validators direction applied to several certified teachers in some lesson subjects such as English, Bahasa, Science, Social and Mathematics lesson and it is included in the learning model that deserves to be used as a self-learning material as well as discussion materials in scientific forums on Experiential Learning-based learning. The model equipped with modules and guidelines is relatively new for most teachers in the North Luwu district so this innovation is very suitable to be applied to areas that are relatively the same as the needs of teachers in North Luwu District. According to Septianti et al., 2020, learning media is important to make learning process more effective and efficient (Septianti et al., 2020). Thus, Experiential Learning proved effective with learning media or modules (Normawati et al., 2021).

The implementation of Experiential Learning-based training model showed that if the activities of four were conducted, the training will be very effective in helping teachers and prospective teacher to improve their competence (Bohon et al., 2017; Kalungwizi et al., 2020; Kang \& Martin, 2018). But in this LCL training model, the learning activities are not limited to activities that involve physical only, for example, emotional elements or training places are also a separate consideration when carrying out learning activities. Therefore, the training help the teacher to ask the extent of their awareness. The issue of diversity both in terms of individuals, management and organizations with such conditions, training activities need to include diverse activities as well. Therefore, in the LCL model-based experiential learning 
training model, activities are not only monotonous on one or two core activities to achieve the goal but several activities involve elements of the participant's internal environment such as reflections on what they feel, think and sharing sessions to ask the extent of their awareness of the importance of training to make a learning implementation plan.

On other studies that have the most similarities with this study showed that the results of pre-and post-survey data, analyzed using Cohen's d analysis, showed a large impact of Experiential Learning on teacher learning, $d>2.00$ for each scale. This showed that the training conducted by the Institute used Experiential Learning proved that this model effective in improving teachers' skills and knowledge in transforming and modifying their teaching methods in teaching English (Bohon et al., 2017). Thus, based on these studies shows that the learning model or training Experiential Learning has a positive impact on the learning objectives to be achieved especially for English teacher. In this research and development, the Experiential Learning LCL model was applied to several certified teachers in some lesson subjects such English, Bahasa, Science, Social and Mathematics lesson. The results of research and development of training model based on Experiential Learning LCL model, showed that the teachers having new experiences in improving their competences in designing learning. It also proves the truth of opinion which states that if Experiential Learning is seen as a theory of learning then Experiential Learning theory is dynamic and holistic, so that this theory of learning applies to all learners who learn from experience, can be from anyone, present in every human activity at all times (Kolb \& Kolb, 2017). It is proven Experiential Learning theory that is holistic (comprehensive) and dynamic related to the learning cycle, also applies and can be used among certified teachers in North Luwu Regency. This showed that Experiential Learning is effective, widely used for various purposes (Barida, 2018; Bennett et al., 2019; Kolb \& Kolb, 2009). Furthermore, to activities in learning other dimensions contribute to the formation of knowledge from experiences that are transformed through learning, namely the elements of place, emotional, sense, thinking and being. This shows that both external and internal environments affect the formation of knowledge and skills (Jose et al., 2017). From the whole discussion, the learning model based on the LCL Experiential Learning model that has been developed by utilizing Borg and Gall model that is modified with Dick \& Carey Model in the development stage is effective to improve teacher competence This model definitely having more detail and variety activities particularly on each tumbler. It is not physical activities only but emotional elements or training places are also a separate consideration when carrying out learning or training activities.

\section{Conclusions and Suggestions}

The training model has been validated and tested for effectiveness to improve the competence of teachers in designing learning. And can be used independently by schools or related agencies that are interested in improving teacher competence in designing learning. Especially for teachers, principals and education offices in North Luwu Regency. The limitations of this research are first, the product in the form of this training model was only developed based on the condition of certified teachers and the environment in public junior high schools in North Luwu Regency, South Sulawesi Province.The second, the limited product development is carried out until the seventh step of Borg and Gall's R\&D by the research has reached the minimum goals set. Based on the conclusion above, researchers suggest some suggestions for the Education Office of North Luwu Regency, the results of research and development in the form of this training model can be used as an alternative training to improve teacher competence, especially in designing learning that meets the elements of the 21st century learning paradigm and it has been completed by training tools such as module, guides and necessary hands-out.

\section{References}

Astutik, K. F., \& Roesminingsih, E. (2021). The Improvement of Teachers 'Professional 


\section{Competency Through Hots-Based Training. 10(1), 145-151.} https://doi.org/10.23887/jpi-undiksha.v10i1.22407.

Barida, M. (2018). Model Experiential Learning dalam Pembelajaran untuk Meningkatkan Keaktifan Bertanya Mahasiswa. Jurnal Fokus Konseling, 4(2), 153. https://doi.org/10.26638/jfk.409.2099.

Bennett, R., Oliver, J. E., Bennett, R., \& Oliver, J. E. (2019). Experiential learning. Acceptance and Commitment Therapy, 89-90. https://doi.org/10.4324/9781351056144-37.

Bohon, L. L., McKelvey, S., Rhodes, J. A., \& Robnolt, V. J. (2017). Training for content teachers of English Language Learners: using experiential learning to improve instruction*. Teacher Development, 21(5), 609-634. https://doi.org/10.1080/13664530.2016.1277256.

Breunig, M. (2017). Experientially learning and teaching in a student- directed classroom. Journal of Experiential Education, 40(3), 213-230. https://doi.org/10.1177/1053825917690870.

Clarke, T. (2017). Engaged Journalism: Using Experiential Learning Theory (ELT) for InClass Journaling Activities. International Journal of Teaching and Learning in Higher Education, 29(1), 154-161.

Coker, J. S., Heiser, E., Taylor, L., \& Book, C. (2017). Impacts of experiential learning depth and breadth on student outcomes. Journal of Experiential Education, 40(1), 5-23. https://doi.org/10.1177/1053825916678265.

Fathorrahman. (2017). Kompetensi pedagogik, profesional, kepribadian, dan kompetensi sosial dosen. Akademika, 15(1), 1-6.

Gunawan, A. I., Rafdinal, W., Amalia, F. A., Hardiyanto, N., \& Saefuloh, D. (2020). Pengembangan Model Pelatihan Berbasis Kinerja bagi Peningkatan Kompetensi Pimpinan Perusahaan Startup. Edunomic Jurnal Pendidikan Ekonomi, 8(1), 43. https://doi.org/10.33603/ejpe.v8i1.2832.

Hakim, A. (2015). Contribution of Competence Teacher (Pedagogical, Personality, Professional Competence and Social) On the Performance of Learning. The International Journal Of Engineering And Science, 4(2), 1-12.

Herminayu, H., \& Sulasmono, B. S. (2020). Pengembangan Modul Pelatihan Model Pembelajaran BCCT Bagi Guru dan Kepala Taman Kanak-Kanak. Jurnal Obsesi : Jurnal Pendidikan Anak Usia 1112. https://doi.org/10.31004/obsesi.v4i2.512.

Hidayat Ada, J., \& Azisah, S. (2016). the Contribution of Teachers' Pedagogical Competence Toward the Effectiveness of Teaching of English At Mtsn Balang-Balang. ETERNAL (English, Teaching, Learning and Research Journal), 2(2), 238-251. https://doi.org/10.24252/eternal.v22.2016.a5.

Ibrahim, R., Boerhannoeddin, A., \& Bakare, K. K. (2017). The effect of soft skills and training methodology on employee performance. European Journal of Training and Development, 41(4), 388-406. https://doi.org/10.1108/EJTD-08-2016-0066.

Jose, S., Patrick, P. G., \& Moseley, C. (2017). Experiential learning theory: the importance of outdoor classrooms in environmental education. International Journal of Science Education, Part B: Communication and Public Engagement, 7(3), 269-284. https://doi.org/10.1080/21548455.2016.1272144.

Kalungwizi, V. J., Krogh, E., Gjøtterud, S. M., \& Mattee, A. (2020). Experiential strategies and learning in environmental education: lessons from a teacher training college in Tanzania. Journal of Adventure Education and Outdoor Learning, 20(2), 95-110. https://doi.org/10.1080/14729679.2018.1555047.

Kang, D. Y., \& Martin, S. N. (2018). Improving learning opportunities for special education needs (SEN) students by engaging pre-service science teachers in an informal experiential learning course. Asia Pacific Journal of Education, 38(3), 319-347. https://doi.org/10.1080/02188791.2018.1505599.

Karia, A. O., \& Omari, S. (2017). Importance of Compensation and Benefits on Performance of Public Water Utilities in Tanzania Importance of Compensation and Benefits on 
Performance of Public Water. Afrian Journal of Business Management, January 2015, 9-18.

Kolb, A. Y., \& Kolb, D. A. (2009). Experiential learning theory: A dynamic, holistic approach to management learning, education and development. The SAGE Handbook of Management Learning, Education and Development, May 2015, 42-68. https://doi.org/10.4135/9780857021038.n3.

Kolb, A. Y., \& Kolb, D. A. (2017). Experiential Learning Theory as a Guide for Experiential Educators in Higher Education. ELTHE: A Journal for Engaged Educators, 1(1), 745. https://nsuworks.nova.edu/elthe/vol1/iss1/7.

Kumar, D. D., \& Siddika, H. (2020). Benefits of Training and Development Program on Employees' Performance: a Study With Special Reference To Banking Sector in Bangladesh. International Journal of Research -GRANTHAALAYAH, 5(12), 77-88. https://doi.org/10.29121/granthaalayah.v5.i12.2017.475.

Kunter, M., Klusmann, U., Baumert, J., Richter, D., Voss, T., \& Hachfeld, A. (2013). Professional competence of teachers: Effects on instructional quality and student development. Journal of Educational Psychology, 105(3), 805-820. https://doi.org/10.1037/a0032583.

Lase, D. (2019). Education and Industrial Revolution 4.0. Handayani Journal PGSD FIP Unimed, 10(1), 48-62. https://doi.org/10.24114/jh.v10i1.14138.

Mason, C., \& Arshed, N. (2013). Teaching Entrepreneurship to University Students through Experiential Learning: A Case Study. Industry and Higher Education, 27(6), 449-463. https://doi.org/10.5367/ihe.2013.0180.

Matsuo, M. (2014). Instructional skills for on-the-job training and experiential learning: An empirical study of Japanese firms. International Journal of Training and Development, 18(4), 225-240. https://doi.org/10.1111/ijtd.12035.

Mawardi. (2018). Merancang model dan media pembelajaran. Scholaria: Jurnal Pendidikan Dan Kebudayaan, 8(1), 26-40. http://ejournal.uksw.edu/scholaria/article/view/1412.

Nabila, H. (2011). The Influence of Pedagogic Competence and Professional Competence To Performance of Teachers' Social Studies in Trowulan District. International Conference on Ethics of Business, Economics, and Social Science, 556-565.

nasdi, R. yuhanda, \& Afriansyah, H. (2019). Standar Pendidik dan Tenaga Kependidikan. https://doi.org/10.31227/osf.io/r95vn.

Normawati, Y. I., Ishartiwi, I., Mumpuniarti, M., \& Maslahah, S. (2021). Development of Functional Academic Guidebook Based on Experiential Learning for Teacher Specialized in Teaching Children with Intellectual Disability. International Journal of Educational Research Review, 63-74. https://doi.org/10.24331/ijere.824229.

Novauli. M, F. (2015). Kompetensi Guru Dalam Peningkatan Prestasi Belajar Pada Smp Negeri Dalam Kota Banda Aceh. Jurnal Administrasi Pendidikan: Program Pascasarjana Unsyiah, 3(1), 45-67.

Nusanti, I.-. (2017). Pengembangan Pendekatan Diklat Bahasa Inggris Untuk Peningkatan Kapasitas Peserta Diklat. Jurnal Pendidikan Dan Kebudayaan, 2(2), 211. https://doi.org/10.24832/jpnk.v2i2.646.

Permana, N. S. (2017). Peningkatan mutu tenaga pendidik dengan kompetensi dan sertifikasi guru. Studia Didaktika: Jurnal Ilmiah Bidang Pendidikan, 11(1), 1-8.

Prihidayanti, Y., Florentinus, T. S., \& Kustiono. (2019). The Effect of The Education and Training Program of Continuous Professional Development Program of In On In Modes on Pedagogical and Professional Competence of Teachers in Kendal. Innovative Journal of Curriculum and Educational Technology, 8(2), 90-97.

Sa'adah, F. N., Widiharih, T., \& Rahmawati, R. (2017). Analisis kovarian pada rancangan bujursangkar graeco latin. Jurnal Gaussian, 6(1), 31-40.

Septianti, A. S., Purnomo, M. E., \& Indrawati, S. (2020). Learning Media Development of Analyzing Poetry-Building Element Using Sparkol Videoscribe. 9(4), 586-596. https://doi.org/10.23887/jpi-undiksha.v9i4.28251.

Shoulders, C. W., Wyatt, J. D., \& Johnson, D. M. (2014). Demonstrations and lectures about solar energy in Arkansas: The importance of experiential learning. Energy Research 
and Social Science, 4(C), 100-105. https://doi.org/10.1016/j.erss.2014.10.002.

Slameto, Sulasmono, B. S., \& Wardani, K. W. (2017). Peningkatan Kinerja Guru Melalui Pelatihan Beserta Faktor Penentunya. Jurnal Pendidikan IImu Sosial, 27(2), 38-47. http://journals.ums.ac.id/index.php/jpis/article/view/5718/3708.

Suherman, A. (2014). Pengembangan Model Program Pelatihan Profesi Untuk Meningkatkan Kompetensi Pedagogis Mahasiswa Pgsd Penjas. Jurnal Cakrawala Pendidikan, 1(1), 138-146. https://doi.org/10.21831/cp.v1i1.1870.

Tanjung, L. (2019). Vlog Experiental Learning Pada Materi Teknik Fermentasi Tempe Produk Bioteknologi. Pedagogia, 17(3), 273-279. https://doi.org/10.17509/pdgia.v17i3.20820.

Tyagita, B. P. A., \& Iriani, A. (2018). Strategi Peningkatan Kompetensi Pedagogik Guru Untuk Meningkatkan Mutu Sekolah. Kelola: Jurnal Manajemen Pendidikan, 5(2), 165-176. https://doi.org/10.24246/j.jk.2018.v5.i2.p165-176.

Verdina, R., Gani, A., \& Sulastri. (2018). Improving students' higher order thinking skills in thermochemistry concept using worksheets based on 2013 curriculum. Journal of Physics: Conference Series, 1088. https://doi.org/10.1088/1742-6596/1088/1/012105.

Widyaningrum, W., Sondari, E., \& Mulyati. (2019). Meningkatkan Kompetensi Profesionalisme Guru Di Abad 21 Melalui Pelatihan Pembelajaran Bahasa Inggris. DEDIKASI: Jurnal Pengabdian Masyarakat, 1(1), 35-44. https://ejournal.metrouniv.ac.id/index.php/JPM/article/view/1600.

Wilson, J. P., \& Beard, C. (2003). The learning combination lock - an experiential approach to learning design. Journal of European Industrial Training, 27, 88-97. https://doi.org/10.1108/03090590310468912.

Wulandari, M. R., \& Iriani, A. (2018). Pengembangan Modul Pelatihan Pedagogical Content Knowledge (PCK) Dalam Meningkatkan Kompetensi Profesional dan Kompetensi Pedagogik Guru Matematika SMP. Kelola: Jurnal Manajemen Pendidikan, 5(2), 177189. https://doi.org/10.24246/j.jk.2018.v5.i2.p177-189.

Zendrato, J. (2016). Tingkat Penerapan Rencana Pelaksanaan Pembelajaran Dalam Pelaksanaan Pembelajaran Di Kelas Suatu Studi Kasus di SMA Dian Harapan Jakarta. Scholaria: Jurnal Pendidikan Dan Kebudayaan, 6(2), 58. https://doi.org/10.24246/j.scholaria.2016.v6.i2.p58-73. 